\title{
GAMBARAN PENGETAHUAN IBU TENTANG GANGGUAN PEMUSATAN PERHATIAN HIPERAKTIF (GPPH) DI TK BIDAYATUL HIDAYAH MEDAN TAHUN 2015
}

\author{
Elizawarda \\ Jurusan Kebidanan
}

\begin{abstract}
Abstrak
Melihat banyaknya angka kejadian GPPH pada anak, maka peneliti tertarik untuk mengadakan penelitian tentang Gambaran Pengetahuan Ibu yang Mempunyai Anak Hiperaktif Di TK Bidayatul Hidayah Medan Tahun 2015. Berdasarkan latar belakang di atas, penulis dapat merumuskan masalah "Bagaimana Gambaran Pengetahuan Ibu yang Mempunyai Anak Hiperaktif Di TK Bidayatul Hidayah Medan Tahun 2015? Yang mana tujuannya adalah untuk mengetahui Gambaran Pengetahuan Ibu yang Mempunyai Anak Hiperaktif Di TK Bidayatul Hidayah Medan Tahun 2015. Sebagai dasar atau bahan masukan dan sumber bacaan bagi peneliti selanjutnya tentang anak hiperaktif. Pengambilan sample dalam penelitian ini menggunakan teknik total sampling, yaitu semua populasi dijadikan sampel.Data yang dikumpulkan dalam penelitian ini adalah data primer yaitu data yang diperoleh langsung dari responden dengan mengedarkan yang berisikan daftar pertanyaan dengan pilihan jawaban yang telah disiapkan. Instrumen dalam penelitian ini adalah kuesioner yang berisikan 20 pertanyaan yang berhubungan dengan pengetahuan ibu tentang anak hiper aktif. Analisa data dilakukan secara deskriptif dengan presentase data yang terkumpul dan disajikan dengan distribusi frekuensi. Kemudian dilakukan pembahasan dengan menggunakan teori kepustakaan dan membandingkan dengan hasil penelitian yang ada setelah itu membuat suatu kesimpulan.
\end{abstract}

\section{Kata Kunci :}

\section{PENDAHULUAN}

\subsection{Latar Belakang}

Akhir-akhir ini, banyak dijumpai keluhan dari para orang tua maupun guru bahwa usia 7 atau 8 tahun, anak belum juga bisa membaca, atau bila mendapatkan tugas, tugasnya tidak diselesaikan. Ada pula keluhan, anak sering tampak melamun di kelasnya atau sering mempermainkan alat tulisnya, dan banyak keluhan senada yang diungkapkan sehubungan dengan tumbuh dan berkembangnya anak. Yang mana, apabila ditelaah lebih lanjut keluhan-keluhan tersebut, maka terdapat kemungkinan anak yang dimaksudkan menunjukkan Gangguan Pemusatan Perhatian (GPP) atau Gangguan Pemusatan Perhatian disertai dengan Hiperaktifitas (GPPH), khususnya ditunjukkan oleh cara dan prestasi belajarnya (Mulyono, R, 2013).

Membesarkan anak-anak yang penuh vitalitas dan sangat energi, bagi kebanyakan orang tua sungguh bukan tugas yang mudah. Bagi orang tua yang anaknya mengalami Gangguan Pemusatan Perhatian dan Hiperaktif $(\mathrm{GPPH})$, tugas tersebut bisa sangat melelahkan, menjengkelkan, bahkan sering kali menyebabkan keluarga yang bersangkutan terkucil dari pergaulan (Mulyono, R, 2013).

Anak yang mengalami GPPH seringkali diberi label sebagai anak yang menyusahkan, malas, nakal, bodoh, biang ribut, emosional, sulit diatur dan sebagainya, baik di sekolah maupun di rumah. Labelitas ini sangat berpengaruh terhadap pembentukan konsep diri anak dan membuat anak merasa tidak dihargai, minder, frustasi, depresi dan sampai kepada menampilkan reaksi penolakan terhadap lingkungan dengan perilaku-perilaku yang semakin tidak diharapkan, seperti: bandel, melawan, membangkang, agresif, dan pemarah. Bila keadaan tersebut tidak ditangani dengan baik pada masa anak, persoalanpun akan memuncak pada masa pubertas dan akan muncul perilaku-perilaku yang semakin tidak diharapkan (Mulyono, R, 2013).

GPPH dapat mengenai siapa saja, dari Negara manapun dan budaya manapun. Rata-rata angka kejadiannya berkisar antara 3\%-10\%. Hal ini, disatu sisi tergantung dengan bagaimana gejala-gejala yang muncul ditanggapi, dan sisi lain dengan melihat kenyataan masalah yang muncul terbanyak serta tergantung pula pada bidangbidang apa saja. Dari laporan kesehatan, prevalensi di luar negeri seperti Belanda persentasenya berkisar antara 2-8\% terdapat pada anak-anak sekolah usia hingga 14 tahun, di mana $2 \%$ merupakan GPPH dengan gejala yang sangat parah, sedang 3-6\% dari mereka merupakan GPPH ringan. Di Amerika, dilaporkan bahwa penyandang GPPH pada anak-anak sekolah sebanyak 5-10\%, di mana angkanya bervariasi dari setiap negara bagian antara $2-14 \%$. Sedangkan hasil penelitian Ukraina didapat angka 20\% hasil (Arga Paernotte dan Jan Buitelaar, 2010). 
Di Indonesia, untuk angka kejadian GPPH belum diketahui secara pasti. Di daerah Jakarta Pusat didapat jumlah sebanyak 4,2\% kasus. Dengan menggunakan instrumen Diagnostic and Statistical Manual for Mental Disorder IV (DSM-IV) didapati angka sebesar 2,2\% untuk tipe hiperaktif dan impulsif, 5,3\% untuk tipe campuran hiperaktif-impulsif dan inatensi, serta 15,3\% untuk GPPH tipe inatensi (Saputro, 2014).

Sementara menurut data dari Unit Psikiatri Anak (Day Care) RSUD Dr.Soetomo Surabaya menunjukkan adanya peningkatan jumlah pasien anak GPPH dengan berbagai karakteristik dari tahun 2000 sampai tahun 2001, yaitu sebesar 43,33\% (dari 60 anak menjadi 86 anak). Sebagai contoh, data jumlah anak GPPH dengan bebagai karakteristik di RSUD Dr.Soetomo, selama tahun 2001 adalah sebanyak 30 anak dengan GPPH yang tanpa disertai gangguan lain (32,29\%), 15 anak dengan GPPH dan gangguan tingkah laku (16,48\%), 8 anak dengan GPPH berspektrum autis $(8,79 \%), 12$ anak dengan GPPG dan epilepsi (13,19\%), 13 anak dengan GPPH dan gangguan berbahasa (14,28\%), 6 anak dengan GPPH dan kecerdasan batas ambang (6,59\%), dan 2 anak GPPH dan anti sosial $(2,20 \%)$. Dari 30 anak GPPH terdapat 21 anak laki-laki (70\%) dan 9 anak perempuan (30\%). Mereka terdiri dari berbagai golongan usia, yaitu 9 anak dengan golongan usia 3-5 tahun (30\%), 18 anak usia 6-8 tahun (60\%), 2 anak usia 9-12 tahun $(6,67 \%)$, dan 1 anak usia di atas 12 tahun (3,33\%). Sedangkan di Yogyakarta, didapatkan angka prevalensi GPPH pada siswa TK sebesar 0,4\% (Mulyono, $\mathrm{R}, 2013)$.

Berdasarkan data tersebut, maka dapat disimpulkan bahwa anak-anak yang menderita GPPH cukup banyak, dikhawatirkan akan menaik tahun demi tahun bila tidak diupayakan penanganan yang lebih baik, dan diperkirakan akan ada 7000 kasus baru setiap tahunnya (Mulyono,R, 2013).

Mempertimbangkan berbagai akibat GPPH pada anak, tindakan penanganan yang tepat perlu segera diberikan. Hal ini, karena dampak buruk yang dialami anak GPPH, tidak hanya merugikan diri sendiri, tetapi juga keluarga, masyarakat dan bangsa (Mulyono, R, 2013).

Berdasarkan survey awal yang dilakukan pada bulan Desember Tahun 2015 di TK Bidayatul Hidayah Medan, penulis melihat banyaknya anak yang hiperaktif sehingga para orang tua nyaris kewalahan dalam menghadapi anak-anak tersebut.

Melihat banyaknya angka kejadian GPPH pada anak, maka peneliti tertarik untuk mengadakan penelitian tentang Gambaran Pengetahuan Ibu yang Mempunyai Anak Hiperaktif Di TK Bidayatul Hidayah Medan Tahun 2015.

\subsection{Perumusan Masalah}

Berdasarkan latar belakang di atas, penulis dapat merumuskan masalah "Bagaimana Gambaran Pengetahuan Ibu yang Mempunyai Anak Hiperaktif Di TK Bidayatul Hidayah Medan Tahun 201

\subsubsection{TujuanUmum}

Untuk mengetahui Gambaran Pengetahuan Ibu yang Mempunyai Anak Hiperaktif Di TK Bidayatul Hidayah Medan Tahun 2015.

\subsubsection{Tujuan Khusus}

1. Untuk mengetahui distribusi pengetahuan ibu tentang anak hiperaktif berdasarkan umur.

2. Untuk mengetahui distribusi pengetahuan ibu tentang anak hiperaktif berdasarkan pendidikan.

3. Untuk mengetahui distribusi pengetahuan ibu tentang anak hiperaktif berdasarkan pekerjaan.

4. Untuk mengetahui distribusi pengetahuan ibu tentang anak hiperaktif berdasarkan sumber informasi.

\subsection{Manfaat Penelitian}

Manfaat penelitian ini adalah :

1. Bagi Kepala Sekolah dan Guru TK Bidayatul Hidayah Medan

Sebagai bahan masukan kepada kepala sekolah dan guru yang berhubungan dengan anak hiperaktif untuk diambil suatu kebijakan.

2. Bagi Institusi Pendidikan Akademi Kebidanan Bakti Inang Persada Medan Sebagai masukan dan menambah pengetahuan para dosen dan mahasiswi tentang anak hiperaktif.

3. Bagi Peneliti selanjutnya

Sebagai dasar atau bahan masukan dan sumber bacaan bagi peneliti selanjutnya tentang anak hiperaktif.

\section{TINJAUAN PUSTAKA}

\subsection{Pengetahuan}

\subsubsection{Defenisi pengetahuan}

Pengetahuan adalah merupakan hasil " tahu " dan ini terjadi setelah orang melakukan penginderaan terhadap suatu objek tertentu, penginderaan melalui panca indra manusia yakni indra penglihatan, pendengaran, penciuman rasa, dan raba. Sebagian besar pengetahuan diperoleh melalui mata dan telinga. (Notoadmodjo, 2007).

Pengetahuan atau kognitif merupakan domain yang sangat penting untuk terbentuknya tindakan seseorang (over behavior). (Notoatmodjo, 2007).

\subsubsection{Proses Adopsi Perilaku}

Dari pengalaman penelitian terbukti perilaku yang disadari oleh pengetahuan akan lebih langgeng daripada perilaku yang tidak disadari oleh pengetahuan.Sebelum orang menghadapi perilaku baru (berprilaku baru), di dalam diri orang tersebut terjadi proses yang berurutan (Notoatmodjo, 2007) yaitu :

1. Awarnes (kesadaran), yakni orang tersebut menyadari dalam arti mengetahui stimulasi (objek) terlebih dahulu. 
2. Interest, yakni orang mulai tertarik kepada stimulasi.

3. Evaluation (menimbang-nimbang baik dan tidaknya stimulasi tersebut bagi dirinya.

4. Trial, orang telah berprilaku baru sesuai dengan pengetahuan, kesadaran dan sikapnya terhadap stimulasi.

5. Adoption (menerima), dimana subjek sudah berprilaku baru sesuai dengan pengetahuan, kesadaran dan sikapnya terhadap stimulasi.

\subsubsection{Tingkatan pengetahuan}

Menurut Notoadmodjo (2007), pengetahuan mempunyai 6 tingkatan yaitu ;

1. Tahu (know)

Tahu diartikan sebagai mengingat suatu materi yang dipelajari sebelumnya. Termasuk ke dalam pengetahuan tingkat ini adalah mengingat kembali (recall) terhadap suatu yang spesifik dari seluruh bahan yang dipelajari satu rangsangan yang telah diterima. Oleh sebab itu tahun ini merupakan tingkat pengetahuan yang paling rendah, kata kerja untuk mengukur bahwa orang tahu tentang apa yang dipelajari antara lain menyebabkan, menguraikan, mendefinisikan, menyatakan dan sebagainya.

2. Memahami (Comperehension)

Memahami diartikan sebagai kemampuan untuk menggunakan menjelaskan secara benar tentang objek yang diketahui. Dan dapat menginterprestasikan materi tersebut secara benar. Orang yang telah paham terhadap objek atau materi harus dapat menjelaskan, menyebutkan contoh, menyimpulkan, meramalkan dan sebagainya terhadap objek yang dipelajari (Notoadmodjo, 2007), Misalnya dapat menjelaskan kenapa harus makan makanan yang bergizi.

3. Aplikasi (Application)

Aplikasi diartikan sebagai kemampuan untuk menggunakan materi yang telah dipelajari pada situasi atau kondisi real atau sebenarnya. Aplikasi di sini dapat diartikan sebagai aplikasi atau kegunaan hukum-hukum, rumus, metode, prinsip dan sebagainya dalam konteks atau situasi yang lain. Misalnya dapat menggunakan rumus statistik dalam perhitungan-perhitungan hasil penelitian, dapat menggunakan prinsip-prinsip, siklus, pemecahan masalah dari kasus-kasus yang diberikan.

4. Analisis (Analiysyis)

Analisis adalah suatu harapan untuk menjabarkan materi atau suatu objek dalam komponenkomponen, tetapi masih di dalam struktur organisasi tersebut dan masih ada kaitannya dengan yang lain. Kemampuan analisis ini dapat dilihat dari penggunaan kata kerja dapat menggambarkan, membedakan, memisahkan, mengkelompokkan dan sebagainya.
5. Sintesis (Synthesis)

Sintesis menunjukkan kepada kemampuan untuk menghubungkan bagian-bagian dalam suatu bentuk keseluruhan yang baru. Dengan kata lain sintesis adalah suatu kemampuan untuk menyusun formulasi baru dan formulasiformulasi yang ada misalnya : dapat menyusun, merencanakan, meningkatkan, menyesuaikan dan sebagainya terhadap suatu rumusan-rumusan yang telah ada.

6. Evaluasi (Evaluation)

Evaluasi ini dikaitkan dengan kemampuankemampuan untuk melakukan identifikasi atau menilai penilaian terhadap suatu materi atau objek. Penilaian-penilaian ini berdasarkan kriteria yang ada. Pengukuran pengetahuan dapat dilakukan dengan wawancara atau angket yang menanyakan kemateri yang ingin diukur dan objek penelitian atau responden.

\subsubsection{Faktor-faktor yang mempengaruhi pengetahuan \\ 1. Umur}

Umur adalah lamanya hidup dalam hidup dihitung sejak dilahirkan sampai usia dimiliki sekarang (Yandianto, 2000). Umur sangat erat hubungannya dengan tingkat pengetahuan seseorang karena semakin bertambahnya umur manusia semakin banyak pula pengalaman yang didapatnya (Notoatmodjo, 2007).

Semakin tua umur seseorang, maka proses-proses perkembangan mentalnya bertambah baik. Akan tetapi pada umur tertentu, bertambahnya proses perkembangan mental ini tidak secepat seperti ketika berumur belasan tahun. Memang daya ingat seseorang itu salah satunya dipengaruhi oleh umur. Dari uraian ini maka dapat disimpulkan bahwa bertambahnya umur seseorang dapat berpengaruh pada pertambahan pengetahuan yang diperolenhya, akan tetapi pada umur-umur tertentu atau menjelang usia lanjut kemempuan penerimaan atau mengingat suatu pengetahuan akan berkurang (Hendra, 2008).

Menurut Manuaba (1998), kelompok umur ibu dibagi menjadi 3 kelompok yaitu: umur ibu <20 tahun, 2035 tahun dan umur $>35$ tahun.

Usia dibawah 20 tahun merupakan masa individu untuk mengubah perilaku kekanak-kanakan dan mengadakan persiapan untuk menghadapi masa dewasa. Masa ini merupakan masa untuk memiliki sikap menerima perubahan keadan fisik yang terjadi, sikap mencari identitas diri,sikap membentuk nilai-nilai yang sesuai dengan orang dewasa serta menerima peran dewasa (Widayatun, 2010)

Usia dewasa awal dimulai ketika individu berusia 20 tahun dan berakhir pada 30 tahun. Periode dewasa awal merupakan perioda masa remaja yang mencari identitas diri kemasa yang lebih tenang untuk menghadapi masa mandiri, masa bekerja dan masa kratif. Sikap positif dan pengetahuan cukup terkait dengan kesiapan wanita menerima perubahan yang terjadi pada diri kita.(Widayatun, 2010). 
Dewasa awal adalah periode masa reproduksi. Masa ini merupakan masa yang tepat untuk menjalani peran seks dewasa karena seorang telah mampu menerima keadaan fisik dan peran seks dewasa maka ia mampu memilki sikap positif dan pengetahuan cukup terkait dengan kesiapan wanita menerima perubahan yang terjadi pada dirinya (Widayatun, 2010).

Usia dewasa tengah mulai 30 tahun keatas dan berakhir pada usia >35 tahun. Masa dewasa tengah merupakan masa usia canggung, masa jenuh dan masa sepi. Periode usia tengah ditandai dengan penurunan awal kemauan organ tubuh khususnya organ reproduksi. Wanita yang memasuki usia dewasa mulai mengalami kejenuhan menjalani peran seks dewasa (Widayatun, 2010).

\section{Pendidikan}

Pendidikan secara umum adalah segala upaya yang direncanakan untuk mempengaruhi orang lain baik individu, kelompok dan masyarakat. Sehingga mereka mau melakukan apa yang diharapkan oleh pelaku pendidikan dalam mencari pengetahuannya dan aspek kehidupannya. Tingkat pendidikan mempunyai hubungan erat dengan sosial budaya, politik, ekonomi dan sebagainya. Pendidikan juga merupakan salah satu faktor yang mempengaruhi persepsi seorang lebih mudah menerima ide/teknologi baru (Notoatmodjo, 2007).

Jalur pendidikan terdiri atas formal dan informal yang dapat saling melengkapi. Menurut DEPDIKNAS (2003), jenjang pendidikan formal terdiri atas :

1. Pendidikan Dasar

Yaitu pendidikan umum yang lamanya 6 tahun, di selenggarakan selama 6 tahun di Sekolah Dasar.

2. Pendidikan Menengah

Yaitu pendidikan yang diselenggarakan bagi lulusan pendidikan dasar selama 3 tahun.

3. Pendidikan Tinggi/Diploma

Yaitu pendidikan jenjang yang lebih dari pada pendidikan menengah dijalur pendidikan sekolah

Pendidikan dianggap memiliki peranan penting dalam menentukan kualitas manusia, dalam hal ini pendidikan berperan untuk membuat kehidupan yang lebih baik sebab makin tinggi pendidikan seseorang semakin banyak pengetahuannya dengan seseorang yang tigkat pendidikannya rendah. Melalui pendidikan manusia diharapkan dapat membangun keberadaan hidupnya dengan lebih baik. Semakin tinggi pendidikan, hidup manusia semakin berkualitas. (Notoatmodjo, 2007).

Pendidikan mempunyai pengaruh penting dalam pembentukan pengetahuan, dikarenakan pendidikan meletakkan dasar pengertian dan konsep moral dalam individu. Dasar pengertian dan konsep moral akan sangat menetukan sistem kepercayaan sehingga konsep tersebut ikut berperan di dalam pembentukan pengetahuan tehadap suatu hal. Sekali kepercayaan terbentuk, maka ia akan menjadi dasar pengetahuan seseorang mengenai apa yang diharapkan dari objek itu (Azwar, 2012).

\section{Pekerjaan}

Pekerjaan merupakan suatu kegiatan atau aktivitas seseorang yang dilakukan sehari-hari untuk memperoleh penghasilan baik di sektor formal maupun informal (Ali, 2013).

Pekerjaan sangat berpengaruh terhadap pengetahuan seseorang, di mana seseorang yang mempunyai pekerjaan akan lebih cepat dan mudah untuk mendapatkan informasi. Hal ini karena lebih sering berinteraksi dengan orang lain yang menyebabkan memperoleh informasi dan pengetahuan (Notoatmodjo, 2007).

Pekerjaan sangat berkaitan dengan pengetahuan. Pada umumnya, pekerjaan adalah aktifitas utama yang dilakukan oleh manusia. Bagi ibu-ibu yang bekerja akan mempunyai pengaruh terhadap pengetahuan (Wikipedia, 2013).

\section{Sumber Informasi}

Sumber informasi adalah segala sesuatu yang menjadi perantara dalam menyampaikan informasi,merangsang pikiran dan kemampuan seseorang. Orang lain disekitar kita merupakan salah satu di antara komponensosial yang ikut mempengaruhi sikap kita. Seseorang yang kita anggap penting, seseorang yang tidak ingin kita kecewakan, seseorang yang berarti khusus bagi kita dan akan banyak mempengruhi pembentukan sikap yang searah dengan orang yang dianggapnya penting (Notoatmodjo, 2007).

Informasi akan memberikan pengaruh pada pengetahuan seseorang, meskipun seseorang memiliki pendidikan yang rendah tetapi jika mendapatkan informasi yang baik dari berbagai media, hal itu akan meningkatkan pengetahuan seseorang (Hendra, 2012).

Informasi dapat diperoleh dari petugas kesehatan, keluarga atau media massa. Informasi yang diperoleh dari petugas kesehatan dapat berupa penyuluhan,Informasi dari keluarga dapat berupa pengalaman, dan dari media massa berasal dari media elektronik (radio, TV, maupun VCD) sedangkan dari media cetak berupa brosur, buku, majalah, koran dan lain-lain (Ahmadi, 2010).

\subsection{Defenisi Anak}

Usia secara jelas mendefenisikan karakteristik yang memisahkan anak-anak dengan orang dewasa. Namun, mendefenisikan anak-anak dari segi usia dapat menjadi permasalahan besar karena penggunaan defenisi yang berbeda oleh beragam negara dan lembaga internasional. Departement of Child and Adolescent Healt and Development, medefenisikan anak- anak sebagai orang yang berusia di bawah 20 tahun. Sedangkan The Convention on The Rights of the Child mendefenisikan anak-anak sebagai orang yang berusia di bawah 18 tahun. WHO ( 2003 ), mendefenisikan anak-anak antara usia 0-14 tahun karena diusia inilah resiko cenderung menjadi besar (Anton, 2012).

Menurut Badan Pusat Statistik, komposisi penduduk Indonesia menurut kelompok umur terdiri dari penduduk berusia muda (0-14 tahun), usia produktif (15-64 tahun) dan usia tua ( $\geq 65$ tahun) (Anton, 2012).

Masa perkembangan anak dibagi oleh banyak ahli dalam beberapa periode dengan tujuan untuk mendapatkan wawasan yang jelas tentang defenisi dan perkembangan anak. Hal ini disebabkan karena pada saat- 
saat perkenbangan tertentu anak-anak secara umum memperlihatkan ciri-ciri dan tingkah laku karakteristik yang hampur sama. Periode perkembangan anak terdiri dari masa bayi usia 0-1 tahun (periode vital), masa kanakkanak usia 1-5 tahun (periode estatis), masa anak- sekolah dasar 6-12 tahun (periode intelektual) dan periode pueral usia 12-14 tahun (pra-pubertas atau pubertas awal) (Anton, 2012).

\subsection{Hiperaktif \\ 2.3.1 Defenisi Hiperaktif}

Ditinjau secara psikologis, hiperaktif adalah gangguan tingkah laku yang tidak normal, disebabkan disfungsi neurologis dengan gejala utama tidak mampu memusatkan perhatian. Hiperaktif merupakan turunan dari Gangguan Pemusatan Perhatian dan Hiperaktif (GPPH). Gangguan ini disebabkan kerusakan kecil pada sistem saraf pusat dan otak sehingga rentang konsentrasi penderita jadi sangat pendek dan sulit dikendalikan (Mulyono, R, 2013).

Gangguan Pemusatan Perhatian dan Hiperaktifitas (GPPH), yang sering disebut juga hanya dengan hiperaktifitas (hyperaktifity), digunakan untuk menyatakan suatu pola perilaku pada seseorang yang menunjukkan sikap tidak mau diam, tidak mau menaruh perhatian dan impulsif (semaunya sendiri) (Mulyono, R, 2013).

Hiperaktifitas juga mengacu kepada tidak adanya pengendalian diri, seperti mengambil keputusan atau kesimpulan tanpa memikirkan akibat-akibat yang mungkin timbul, dan sering menyebabkan pelakunya terkena hukuman atau mengalami kecelakaan (Mulyono, R, 2013).

\subsubsection{Anak Hiperaktif}

Anak hiperaktif adalah anak yang luar biasa banyak bergerak dan sering kali tidak dapat dikendalikan, tidak tenang, dan tidak dapat berkonsentrasi (Patternote, A dan Jane, B, 2010).

Anak-anak yang hiperaktif selalu bergerak. Mereka tidak mau diam, bahkan dalam berbagai situasi, misalnya ketika sedang mengikuti pelajaran di kelas yang menuntut agar mereka bersikap tenang. Mereka tidak pernah merasakan asyiknya permainan atau mainan yang umumnya disukai anak-anak seusia mereka, sebentarsebentar mereka bergerak untuk beralih dari permainan atau mainan yang satu ke yang lain. Ini mengandung arti bahwa dari kegiatan-kegiatan yang dilakukan mereka cenderung tidak memperoleh kepuasan sebanyak yang dikehendaki (Mulyono, R, 2013).

Kondisi gangguan perilaku hiperaktifitas (hiperactifity) berkombinasi dengan sifat tertentu, seperti gelisah, tidak mampu berkonsentrasi, serta terus-menerus berbicara. Oleh karena susah berkonsentrasi, sering prestasi sekolahnya menurun. Anak hiperaktif, perilakunya tanpa arah pasti, dan biasanya memiliki rentang perhatian atau konsentrasi sangat pendek dibandingkan dengan temanteman seusianya. Kecendrungan anak hiperaktif yang lain adalah keras kepala dan suka mengabaikan perintah (Mulyono, R, 2013).

Walaupun ia berusaha menyesuaikan diri dan mengikuti peraturan, tetapi ia sering kali tidak berhasil.
Perilakunya yang kacau itu justru mengundang kejengkelan bagi orang-orang di sekitarnya. Akibatnya adalah susah mendapatkan teman dan sahabat. Kondisi ini dapat membawanya pada masalah-masalah emosional, agresif atau sebaliknya perilaku menarik diri dan depresi (Paeternotte, A dan Jan, B, 2014).

\subsubsection{Penyebab Anak Hiperaktif}

Penyebab anak hiperaktif sampai saat ini belum diketahui dengan pasti, namun ada beberapa faktor penyebab yang diduga merupakan penyebabnya, antara lain faktor neurobiologis (gangguan saraf), genetis (keturunan), akuisital (didapat setelah lahir), serta psikososial (kejiwaan dan lingkungan). Terjadinya hiperaktif diperkirakan berkaitan dengan berbagai macam gangguan yang berpengaruh pada fungsi otak.

Ada juga penyebab lainnya, yakni: tempramen bawaan, pengaruh lingkungan, malfungsi otak, serta epilepsi. Bisa juga gangguan di kepala, seperti gegar otak, trauma kepala karena persalinan sulit atau pernah terbentur, infeksi, keracunan, gizi buruk dan alergi makanan (Mulyono, R, 2013).

Ada beberapa faktor yang dicurigai ikut berperan terhadap terjadinya hiperaktif, antara lain (Mulyono, R, 2013) :

1. Genetik (keturunan).

2. Faktor perkembangan janin (pernah mengalami masalah selama dalam kandungan) dan kelahiran (gangguan proses persalinan).

3. Pengunaan alkohol oleh ibu selama masa kehamilan.

4. Struktur otak tidak normal.

5. Pengaruh kuat keracunan dan kontaminasi lingkungan (misal : polusi udara dengan kandungan timbal tinggi).

6. Alergi makanan (yang mengandung zat aditif seperti pengawet, pewarna, perasa buatan, dan lain-lain, salisilat, dan banyak gula).

7. Kondisi-kondisi kesehatan yang lain (pembengkakan kelenjar tiroid, epilepsi, autis, dan lain-lain.

8. Efek samping dari pengobatan.

9. Keluarga tidak harmonis (perceraian orang tua atau sering terjadinya pertengkaran, peran tanggung jawab orang tua buruk, dan lain-lain).

10. Faktor psikososial (pola asuh lingkungan yang tidak disiplin dan tidak teratur, perbedaan perhatian dan kasih sayang dalam keluarga, dan lain-lain).

11. Ada kemungkinan beberapa faktor di atas saling berinteraksi.

\subsubsection{Ciri-ciri Anak Hiperaktif}

Adapun ciri-ciri anak yang mengalami Gangguan Pemusatan Perhatian dan Hiperaktif (GPPH) adalah sebagai berikut (Zaviera, 2007) :

\section{Tidak fokus}

Anak dengan gangguan hiperaktifitas tidak bisa berkonsentrasi lebih dari lima menit. Dengan kata lain, ia tidak bisa diam dalam waktu lama dan 
mudah teralihkan perhatiannya kepada hal lain. Sering seakan tidak mendengarkan kalau diajak bicara langsung, sering tidak memahami semua instruksi dan gagal menyelesaikan pekerjaan atau tugas, sering kehilangan benda-benda yang perlu untuk tugas atau kegiatan (misalnya mainan, karangan, pensil, buku, atau peralatan), sering mudah terganggu oleh rangsangan berlebihan, sering lupa (alpa) dalam kegiatan sehari-hari.

2. Menentang

Anak dengan gangguan hiperaktifitas umumnya memiliki sikap penentang/pembangkang atau tidak mau dinasihati. Misalnya penderita akan marah jika dilarang berlari ke sana ke mari, coratcoret atau naik-turun tak berhenti. Penolakannya juga bisa ditunjukkan dengan sikap cuek.

3. Destruktif

Perilakunya bersifat destruktif atau merusak. Ketika menyusun lego misalnya, anak aktif akan menyelesaikan dengan baik samua lego tersusun rapi. Sebaliknya, anak hiperaktif bukan menyelesaikannya malah menghancurkan mainan lego yang sudah tersusun rapi. Terhadap barang-barang yang ada di rumah seperti vas atau pajangan lain, kecendrungan anak untuk menghancurkannya juga sangat besar. Oleh karena itu, anak hiperaktif sebaiknya di jauhkan dari barang-barang yang mudah dipegang dan mudah rusak.

4. Tak kenal lelah

Anak dengan hiperaktifitas sering tidak menunjukkan sikap lelah, seperti : ketika duduk, tangan dan kaki sering tidak bisa diam atau duduk dengan resah. Sering meninggalkan kursi di kelas atau situasi lainnya ketika diharapkan tetap duduk manis sering lari ke sana-sini atau banyak memanjat-manjat dalam situasi ketika diharapkan tetap duduk manis, sering tidak bisa diam ketika bermain-main atau melakukan kegiatan waktu luang. Sering bergerak atau sering bertindak seakan "didorong sebuah motor", dan sering berbicara terus-menerus (cerewet).

5. Tanpa tujuan

Semua aktifitas dilakukan tanpa tujuan jelas. Kalau anak aktif, ketika naik ke atas kursi punya tujuan, misalnya ingin mengambil mainan atau bermain peran sebagai Supermen. Anak hiperaktif melakukannya tanpa tujuan, dia hanya naik dan turun kursi saja.

6. Tidak sabar dan usil

Yang bersangkutan juga tidak memiliki sifat sabar, seperti : sering menjawab sebelum pertanyaan selesai, sering tidak sabar menunggu giliran, sering menyela orang lain (misalnya menyela pembicaraan atau permainan).

7. Intelektual rendah

Sering kali intelektualitas anak hiperaktifitas berada di bawah rata-rata anak normal. Mungkin karena secara psikologis mentalnya sudah terganggu sehingga ia tidak bisa menunjukkan kemampuan kreatifnya.

\subsubsection{Kriteria Anak Hiperaktif}

Anak-anak dengan ADHD biasanya menampakkan perilaku yang dapat dikelompokkan dalam 2 kriteria utama, yaitu kurangnya kemampuan memusatkan perhatian dan hiperaktivitas-impulsivitas (Fadhli, 2010).

-Sulit konsentrasi atau kurangnya memusatkan perhatian dan muncul dalam perilaku:

a. Ketidak mampuan memperhatikan detil atau melakukan kecerobohan dalam mengerjakan tugas, bekerja, atau aktivitas lain.

b. Kesulitan memelihara terhadap tugas atau aktivitas bermain.

c. Kadang terlihat tidak perhatian ketika berbicara dengan orang lain.

d. Tidak mengikuti perintah dan kegagalan menyelesaikan tugas.

e. Kesulitan mengorganisasikan tugas dan aktivitas.

f. Kadang menolak, tidak suka, atau enggan terlibat dalam tugas yang memerlukan proses mental yang lama, misalnya tugas sekolah.

g. Sering kehilangan barang miliknya, misalnya mainan, pensil, buku, dan lainlain.

h. Mudah terganggu stimulus dari luar.

i. Sering lupa dengan aktivitas sehari-hari.

-Sedangkan hiperaktivitas-impulsitativ seriang muncul dalam perilaku:

a. Gelisah atau sering menggeliat di tempat duduk.

b. Sering meninggalkan tempat duduk di kelas atau situasi lain di mana seharusnya duduk tenang.

c. Berlari berlebihan atau memanjat-manjat yang tidak tepat situasinya.

d. Pada remaja atau dewasa terbatas pada perasaan tidak dapat tenang atau gelisah.

e. Kesulitan bermain atau terlibat dalamaktivitas yang menyenangkan.

f. Seolah selalu terburu-buru atau bergerak terus seperti mesin.

g. Berbicara terlalu banyak.

h. Sering menjawab pertanyaan sebelum selesai diberikan (impulsivitas).

i. Kesulitan menunggu giliran (impulsivitas)

j. Menyela atau memaksakan pendapat kepada orang lain.

Terkadang gejala tersebut juga diikuti oleh agresivitas dalam bentuk:

a. Sering mendesak, mengancam, atau mengintimidasi orang lain.

b. Sering memulai perkelahian.

c. Menggunakan senjata tajam yang dapat melukai orang lain. 
d. Berlaku kasar secara fisik terhadap orang lain.

e. Menyiksa binatang.

f. Menyanggah jika dikonfrontasi dengan korbannya.

g. Memaksa orang lain dengan melakukan aktivitas seksual.

\subsubsection{Cara Membuat Diagnosa}

Proses diagnostik untuk GPPH yang direkomendasikan,

sedikitnya ada lima tahapan. Adapun langkah-langkahnya sebagai berikut (Mulyono, R, 2013):

\section{Langkah pertama: Mengenali gajala-gejalanya}

Ada dua daftar gejala : pertama, untuk problem yang berhubungan dengan perhatian dan kedua, untuk hiperaktifitas dan sikap semaunya sendiri (impulsiveness). Bila ada enam atau lebih gejala-gejala tersebut dari salah satu dua daftar itu, dan bila gejala-gejala ini sering tampak (tidak hanya kadang-kadang) dan terus bertahan selama paling tidak enam bulan, maka dapat dicurigai menderita GPPH.

Gejala-gejala dari kurang perhatian adalah:

1. Tidak dapat memusatkan perhatian pada detaildetail atau melakukan kesalahan-kesalahan yang ceroboh dalam pekerjaan sekolah atau dalam aktivitas-aktivitas lainnya.

2. Mengalami kesulitan dalam mempertahankan perhatian pada tugas-tugas atau kegiatan bermain.

3. Tampak tidak mendengarkan ketika berbicara secara langsung.

4. Tidak mengikuti instruksi dan tidak dapat menyelesaikan pekerjaan sekolah atau tugastugas, tetapa bukan karena dia tidak mampu memahami instruksi atau karena kenakalan yang disengaja.

5. Mengalami kesulitan mengorganisir tugas dan kegiatan.

6. Menghindari, tidak menyukai atau enggan untuk terlibat dalam tugas-tugas yang membutuhkan usaha mental yang terusmenerus seperti pekerjaan rumah.

7. Kehilangan barang-barang seperti mainan, tugas sekolah, pensil, buku, peralatan, dan pakaian.

8. Mudah terganggu oleh kebisingan, gerakangerakan, atau rangsangan lain.

9. Mudah lupa.

Gejala-gejala dari hiperaktifitas dan sikap semaunya sendiri (impulsiveness) adalah:

1. Suka memainkan tangan atau kaki atau mengeliat-ngeliat di tempat duduk.

2. Meninggalkan tempat duduk di kelas atau meninggalkan meja makan atau kapanpun saat diharuskan dia unntuk duduk tenang.

3. Suka berjalan-jalan atau naik-naik dalam situasi di mana perilaku ini tidak tepat.

4. Terus menerus "sibuk" atau berperilaku seakan-akan "digarakkan oleh tenaga motor".
5. Bicara tanpa henti.

6. Menjawab pertanyaan tanpa berpikir sebelum pertanyaan tersebut selesai.

7. Mengalami kesulitan untuk menunggu giliran dalam permainan atau dalam kegiatan yang terstruktur lainnya.

8. Mengganggu orang lain (mengganggu pembicaraan atau permainan).

\section{Langkah kedua: Menentukan kapan gejala-gejala tersebut pertama muncul}

Bila gejala-gejala tersebut muncul sebelum anak berusia 7 tahun, maka GPPH mungkin terjadi.

\section{Langkah ketiga: Menentukan di mana gejala-gejala tersebut terjadi}

Apakah perilaku anak menjadi masalah hanya ketika ia berada di sekolah atau apakah juga menjadi masalah saat berada di rumah? Bila anak mempunyai problem perilaku dalam dua tempat atau lebih, maka GPPH mungkin terjadi.

Langkah keempat: Menilai tingkat keparahan gejalagejala tersebut

Apakah perilaku anak semata-mata hanya mengganggu, ataukah menyebabkan problem yang nyata bagi anak ketika di sekolah atau dalam situasi sosial? Sebelum membuat diagnosa atas GPPH, membutuhkan bukti yang jelas bahwa GPPH benar-benar menghalangi kemampuan anak untuk melakukan fungsinya di sekolah atau di rumah.

\section{Langkah kelima: Kesampingkan diagnosa yang} mungkin lainnya

Hal yang penting adalah memastikan bahwa problem perilaku tersebut bukan akibat problem atau kelainan lain, seperti keterlambatan perkembangan global atau program-program psikiatrik.

\subsubsection{Tindakan Penanganan}

Tindakan penanganan (terapi) yang efektif yang dapat dilakukan untuk

membantu mengatasi problem-problem GPPH ialah: Terapi Modifikasi

Perilaku, Terapi Diet Makanan, dan Terapi Obat-obatan (Farmasi) (Mulyono,

2003).

1. Terapi Modifikasi Perilaku

Secara umum, Terapi modifikasi perilaku dapat diartikan sebagai hampir segala tindakan yang bertujuan untuk membentuk perilaku yang diharapkan. Terapi modifikasi perilaku dalam prakteknya akan efektif, bila di bawah bimbingan seorang psikolog. Terapi modifikasi perilaku terdiri dari pencegahan (preventif) dan penanganan (kuratif).

a. Pencegahan (preventif):

- Sediakan lingkungan yang sehat.

- Memilih metode kelahiran yang alami.

- Selaraskan stimulasi.

- Ajarkan kegiatan yang bertujuan 
- Mengamati model dan menjadi model.

- Manfaatkan kata-kata.

b. Penanganan (kuratif)

- Beri dorongan verbal.

- Terapkan sistem kontrak atau koin.

\section{Terapi Diet Makanan}

Terapi diet makanan adalah suatu terapi yang mengatur makanan yang dimakan. Pengaturan makanan dilakukan dengan memberikan perhatian dari segi jenis, jumlah, dan frekuensi pemberian makanan.

Popularitas terapi diet makanan sebagai salah satu terapi penanganan perilaku hiperaktifitas dimulai dari penelitian DR.Feingold pada tahun 1870-an. Feingold menyatakan bahwa ada beberapa jenis makanan yang dapat mempengaruhi terjadinya atau meningkatkan perilaku hiperaktifitas pada anak GPPH. Beberapa jenis makanan tersebut ialah jenis makanan yang mengandung zat aditif makanan (pengawet, pewarna, aroma/perasa buatan, dan lainlai), dan salisilat. Feingold berhasil membuktikan bahwa anak-anak hiperaktif sebagai subyek penelitiannya yang sungguh-sungguh menghindari jenis-jenis makanan di atas, menunjukkan adanya penurunan perilaku hiperaktifitas.

Selain makanan yang mengandung zat aditif dan salisilat, ternyata makanan yang mengandung banyak gula juga mempengaruhi terjadinya atau meningkatkan perilaku hiperaktifitas pada anak GPPH. Printz menemukan bahwa gula dapat mempengaruhi timbulnya perilaku kasar-merusak pada anak hiperaktif.

3. Terapi Obat-obatan (Farmasi)

Terapi obat adalah suatu teknik terapi medis dengan pemberian obat dengan dosis tertentu yang diminum teratur untuk penanganan anak GPPH pada anak.

Terapi obat, bila cocok, cenderung memberikan hasil yang lebih dramatis dibandingkan dengan terapi model modifikasi perilaku. Obat stimulans yang banyak digunakan ialah metilfenidat dan amfetamin. Bila efektif, obat stimulans bukan saja performans dalam banyak hal. Pada dosis yang efektif pikiran anak menjadi lebih terorganisir dan kesiagaannya tidak berkurang. Stimulans juga dapat meningkatkan performans pada individu yang normal yangmengalami rasa jemu dan capai. Terapi stimulans biasanya tetap berkhasiat selama bertahun-tahun. Walaupun telah lama digunakan, penghentian obat dapat menyebabkan kambuhnya gejala dalam waktun singkat. Sekitar 50-80\% anak GPPH responsive terhadap terapi dengan obat stimulans, sedangkan sekitar 25\% anak GPPH gagal berespon terhadap obat stimulans atau tidak mendapatkan manfaat dari pengobatan stimulans. Pada dosis yang tinggi, stimulans dapat mencetuskan " $t i c$ " yang akan berhenti bila dosis dikurangi atau obat dihentikan. Puncak aksi obat terjadi pada 2 jam setelah obat diminum dan efeknya menghilang setelah enam jam. Cara pengobatan biasanya di mulai dengan dosis di pagi hari, dan bila perlu diberi lagi pada siang hari bergantuna pada keadaan, dan munngkin tidak dibutuhkan. Bila masalah di rumah cukup berat dapat diberikan dosis ketiga pada sore hari.

\subsection{Kerangka Konsep}

Kerangka konsep penelitian yang berjudul Gambaran Pengetahuan Ibu Tentang Gangguan Pemusatan Perhatian Hiperaktif (GPPH) Di TK Bidayatul Hidayah Medan Tahun 2015.

\section{Variabel Independent \\ Bagan 3.1 Kerangka Konsep}

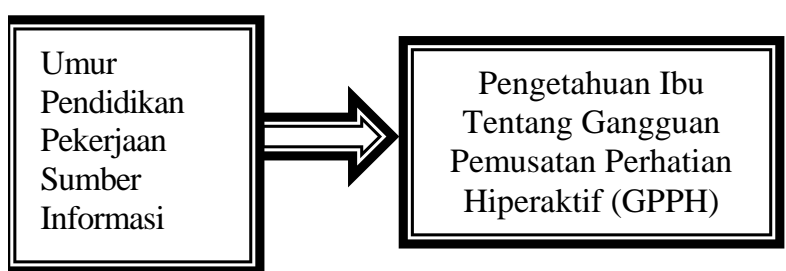

\subsection{Defenisi Operasional}

\subsubsection{Pengetahuan}

Pengetahuan adalah kemampuan ibu untuk menjawab dengan benar pada kuesioner tentang anak hiperaktif.

Kategori :

a. Baik : apabila responden menjawab 16-20 soal dijawab dengan benar.

b. Cukup : apabila responden menjawab 12-15 soal dijawab dengan benar.

c. Kurang : apabila responden menjawab 0-11 soal dijawab dengan benar.

Skala

Alat ukur

: Ordinal

\subsubsection{Umur}

Adalah lamanya hidup responden dihitung sejak lahir hingga pada saat menjawab kuesioner dengan kategori :

a.Usia $<20$ tahun

b.Usia 20-30 tahun

c.Usia $>35$ tahun

Skala ukur : Ordinal

Alat ukur : Kuesioner

\subsubsection{Pendidikan}

Proses pendidikan terakhir yang pernah diselesaikan sesuai dengan jawaban responden pada kusioner.

Kategori :

a. Pendidikan rendah : SD dan SLTP

b. Pendidikan Menengah : SMA sederajat

c. Pendidikan tinggi : Diploma, Sarjana sederajat

Skala ukur : Ordinal

Alat ukur : Kuesioner 


\subsubsection{Pekerjaan Ibu}

Pekerjaan ibu adalah kegiatan formal yang dilakukan ibu dalam kehidupan sehari-hari yang menyebabkan ibu banyak berinteraksi dengan orang lain.

Kategori :

a. Petugas Kesahatan (Dokter, Bidan, Perawat dan petugas kesehatan lainnya)

b. Non Petugas Kesehatan (Guru, Pengusaha, Pedagang dan lain-lain)

c. Tidak Bekerja

Skala ukur : Nominal

Alat ukur : Kuesioner

\subsubsection{Sumber Informasi}

Sumber informasi merupakan segala sesuatu informasi yang pernah diperoleh ibu yang berhubungan dengan Anak GPPH sesuai dengan kategori :

a. Media Massa : TV, radio, majalah, koran, selebaran dan lain-lain

b. Keluarga/kerabat : saudara, teman, tetangga dan lain-lain

c. Petugas kesehatan : Dokter, Bidan, Perawat dan petugas kesehatan lainnya

Skala ukur : Nominal

Alat ukur : Kuesioner

\subsection{Jenis Penelitian}

Jenis penelitian ini adalah Deskriptif atau suatu metode penelitian yang dilakukan dengan tujuan untuk membuat gambaran atau deskripsi tentang suatu keadaan secara objektif sehingga peneliti dapat mengetahui Gambaran Pengetahuan Ibu yang Mempunyai Anak Hiperaktif Di TK Bidayatul Hidayah Medan Tahun 2015.

\subsection{Lokasi dan Waktu Penelitian}

\subsubsection{Lokasi Penelitian}

Penelitian ini dilakukan di TK Bidayatul Hidayah Medan. Alasan peneliti memilih lokasi ini sebagai tempat penelitian adalah :

a. Memiliki jumlah anak dengan GPPH yang cukup.

b. Belum pernah dilakukan penelitian sebelumnya.

\subsubsection{Waktu Penelitian}

Penelitian dilakukan mulai dari bulan November 2014 s/d Juli 2015

\subsection{Populasi dan Sampel}

3.5.1 Populasi

Populasi penelitian ini adalah seluruh ibu-ibu yang di TK Bidayatul Hidayah Medan Tahun 2015 yaitu sebanyak 30 orang.

\subsubsection{Sampel}

Pengambilan sample dalam penelitian ini menggunakan teknik total sampling, yaitu semua populasi dijadikan sampel.

\subsection{Teknik pengumpulan data}

Data yang dikumpulkan dalam penelitian ini adalah data primer yaitu data yang diperoleh langsung dari responden dengan mengedarkan yang berisikan daftar pertanyaan dengan pilihan jawaban yang telah disiapkan.

\subsection{Instrumen Penelitian}

Instrumen dalam penelitian ini adalah kuesioner yang berisikan 20 pertanyaan yang berhubungan dengan pengetahuan ibu tentang anak hiper aktif.

\subsection{Pengolahan Data}

Pengolahan data dilakukan dengan memakai teknik manual, pelaksanaannya

dilakukan sebagai berikut :

a. Editing

Dilakukuan pengecekan kelengkapan data yang telah terkumpul, bila terdapat kesalahan dan kekeliruan dalam pengumpulan data yang di periksa, maka akan diperbaiki.

b. Coding

Data yang telah diedit diubah dalam bentuk angka (kode), nama responden diubah menjadi nama kode responden.

\section{c. Tabulating}

Untuk memperoleh analisa data dan pengolahan data serta pengambilan, keputusan dimasukkan dalam bentuk distribusi frekuensi, memberi skor terhadap soalsoal yang diberikan kepada masyarakat.

\subsection{Analisa data}

Analisa data dilakukan secara deskriptif dengan presentase data yang terkumpul dan disajikan dengan distribusi frekuensi. Kemudian dilakukan pembahasan dengan menggunakan teori kepustakaan dan membandingkan dengan hasil penelitian yang ada setelah itu membuat suatu kesimp

\section{Hasil}

Dari hasil penelitian yang telah dilakukan oleh peneliti di TK Bidayatul Hidayah Medan dengan judul "Gangguan Pemusatan Perhatian Hiperaktif (GPPH) Di TK Bidayatul Hidayah Medan" di peroleh hasil penilaian pengetahuan ibu tentang anak hiperaktif dan disajikan dalam bentuk tabel berikut ini :

\subsubsection{Pengetahuan Ibu}

Perolehan data yang didapat dari penelitian terhadap pengetahuan ibu yang mempunyai anak hiperaktif di TK Bidayatul Hidayah Medan adalah seperti pada tabel berikut ini :

Tabel 4.1.1 Distribusi Frekuensi Pengetahuan Ibu Tentang Gangguan Pemusatan Perhatian Hiperaktif (GPPH) Di TK Bidayatul Hidayah Medan

\begin{tabular}{|c|c|c|c|}
\hline No & Pengetahuan & $\mathbf{F}$ & $\begin{array}{c}\text { Persentase } \\
(\%)\end{array}$ \\
\hline 1 & Baik & 10 & 34 \\
\hline 2 & Cukup & 12 & 40 \\
\hline 3 & Kurang & 8 & 26 \\
\hline & Total & 30 & 100 \\
\hline
\end{tabular}


Berdasarkan tabel 4.1.1 diketahui bahwa dari 30 responden berpengetahuan cukup sebanyak 12 (40\%) responden, berpengetahuan kurang sebanyak 8 (26\%) responden.

Hasil perolehan data pada Pengetahuan Ibu Tentang Gangguan Pemusatan Perhatian Hiperaktif (GPPH di TK Bidayatul Hidayah Medan, berdasarkan umur dapat dilihat pada tabel berikut ini :

Tabel 4.1.2 Distribusi Frekuensi Pengetahuan Ibu Tentang Gangguan Pemusatan Perhatian Hiperaktif (GPPH) Berdasarkan Umur Di TK Bidayatul Hidayah Medan

\begin{tabular}{|c|c|c|c|c|c|c|c|c|}
\hline \multirow{2}{*}{ Umur } & \multicolumn{6}{|c|}{ Pengetahuan } & \multicolumn{2}{c|}{ Total } \\
\cline { 2 - 8 } & \multicolumn{2}{|c|}{ Baik } & \multicolumn{2}{c|}{ Cukup } & \multicolumn{2}{c|}{ Kurang } & \multicolumn{2}{c|}{} \\
\cline { 2 - 9 } & F & $\%$ & F & \% & F & $\%$ & F & $\%$ \\
\hline$<20$ Tahun & - & - & - & - & - & - & - & - \\
\hline $\begin{array}{c}20-35 \\
\text { tahun }\end{array}$ & 3 & 10 & 11 & 36,67 & 6 & 20 & 20 & 66,67 \\
\hline$>35$ Tahun & 7 & 23,34 & 2 & 6,67 & 1 & 3,34 & 10 & 33,33 \\
\hline Total & 10 & 33,34 & 19 & 43,34 & 7 & 23,34 & 30 & 100 \\
\hline
\end{tabular}

Berdasarkan tabel 4.1.2 diketahui dari 30 reponden mayoritas berusia $20 \quad-35$ tahun yaitu 20 responden dan mayoritas berpengetahuan cukup sebanyak 11 responden $(33,33 \%)$, dan dari responden yang berusia > 35 tahun mayoritas berpengetahuan cukup sebanyak 2 responden $(6,67 \%)$.

\subsubsection{Pengetahuan Ibu Berdasarkan Pendidikan}

Setelah dilakukan penelitian data pada Pengetahuan Ibu Tentang Gangguan Pemusatan Perhatian Hiperaktif di TK Bidayatul Hidayah Medan berdasarkan pendidikan dapat dilihat pada tabel berikut ini :

Tabel 4.1.3 Distribusi Frekuensi Pengetahuan Ibu

$\begin{array}{llr}\text { Tentang } & \text { Gangguan } & \text { Pemusatan } \\ \text { Perhatian } & \text { Hiperaktif } & \text { (GPPH) }\end{array}$

Berdasarkan Pendidikan Di TK Bidayatul Hidayah Medan

\begin{tabular}{|c|c|c|c|c|c|c|c|c|c|}
\hline \multirow{2}{*}{ No } & \multirow{2}{*}{ Pendidikan } & \multicolumn{9}{|c|}{ Pengetahuan } & \multicolumn{3}{c|}{ Total } \\
\cline { 3 - 10 } & & \multicolumn{2}{|c|}{ Baik } & \multicolumn{2}{c|}{ Cukup } & \multicolumn{2}{c|}{ Kurang } & \multicolumn{2}{c|}{} \\
\cline { 3 - 10 } & & F & \% & F & \% & F & \% & F & $\%$ \\
\hline 1 & Dasar & - & - & 2 & 6.7 & 7 & 23,4 & 9 & 30 \\
\hline 2 & Menengah & 4 & 13,4 & 9 & 30 & - & - & 13 & 43 \\
\hline 3 & Tinggi & 6 & 20 & 2 & 6,7 & - & - & 8 & 27 \\
\hline & Total & 10 & 33,4 & 13 & 36,7 & 7 & 23,4 & 30 & 100 \\
\hline
\end{tabular}

Berdasarkan tabel 4.1.3 diketahui 30 responden, dapat dilihat dari 13 responden yang berpendidikan menengah mayoritas berpengetahuan cukup sebanyak 9 responden (30\%), dan dari 9 responden yang berpendidikan dasar mayoritas berpengetahuan cukup sebanyak $2(6,7 \%)$, dan dari 8 responden yang berpendidikan tinggi mayoritas berpengetahuan cukup sebanyak 2 responden $(6,7 \%)$.

\subsubsection{Pengetahuan Ibu Berdasarkan Pekerjaan}

Setelah dilakukan penelitian data pada Pengetahuan Ibu Tentang Gangguan Pemusatan Perhatian Hiperaktif (GPPH)di TK Bidayatul Hidayah Medan berdasarkan pekerjaan dapat dilihat pada tabel berikut ini :
Tabel 4.1.4 Distribusi Frekuensi Pengetahuan Ibu Yang Mempunyai Anak Hiperaktif Berdasarkan Pekerjaan Di TK Bidayatul Hidayah Medan

\begin{tabular}{|c|c|c|c|c|c|c|c|c|c|}
\hline \multirow[t]{3}{*}{ No } & \multirow[t]{3}{*}{ Pekerjaan } & \multicolumn{6}{|c|}{ Pengetahuan } & \multirow{2}{*}{\multicolumn{2}{|c|}{ Total }} \\
\hline & & \multicolumn{2}{|c|}{ Baik } & \multicolumn{2}{|c|}{ Cukup } & \multicolumn{2}{|c|}{ Kurang } & & \\
\hline & & $\mathbf{F}$ & $\%$ & $\mathbf{F}$ & $\%$ & $\mathbf{F}$ & $\%$ & $\mathbf{F}$ & $\%$ \\
\hline 1 & Bekerja & 8 & 26,6 & 7 & 23,3 & 4 & 13,3 & 19 & 63,4 \\
\hline 2 & $\begin{array}{l}\text { Tidak } \\
\text { Bekerja }\end{array}$ & 2 & 6,7 & 5 & 16,6 & 4 & 13,3 & 11 & 36,6 \\
\hline & Total & 10 & 33,3 & 12 & 39.3 & 8 & 26,6 & 30 & 100 \\
\hline
\end{tabular}

Berdasarkan tabel 4.1.4 diketahui dari 30 responden mayoritas bekerja yaitu 19 orang dan mayoritas berpengetahuan cukup sebanyak 7 responden $(23,3 \%)$ dari 11 responden tidak bekerja mayoritas berpengetahuan cukup sebanyak 5 responden $(16,6 \%)$

\subsubsection{Pengetahuan Ibu Berdasarkan Sumber Informasi \\ Setelah dilakukan penelitian data pada} Pengetahuan Ibu Tentang Gangguan Pemusatan Perhatian Hiperaktif (GPPH) di TK Bidayatul Hidayah Medan berdasarkan paritas dapat dilihat pada tabel berikut ini :

Tabel 4.1.5 Distribusi Frekuensi Pengetahuan Ibu Yang Mempunyai Anak Hiperaktif Berdasarkan Sumber Informasi Di TK Bidayatul Hidayah Medan

\begin{tabular}{|c|c|c|c|c|c|c|c|c|c|}
\hline \multirow[t]{3}{*}{ No } & \multirow{3}{*}{$\begin{array}{l}\text { Sumber } \\
\text { informasi }\end{array}$} & \multicolumn{6}{|c|}{ Pengetahuan } & \multicolumn{2}{|c|}{ Total } \\
\hline & & \multicolumn{2}{|c|}{ Baik } & \multicolumn{2}{|c|}{ Cukup } & \multicolumn{2}{|c|}{ Kurang } & & \\
\hline & & $\mathbf{F}$ & $\%$ & $\mathbf{F}$ & $\%$ & $\mathbf{F}$ & $\%$ & $\mathbf{F}$ & $\%$ \\
\hline 1 & $\begin{array}{l}\text { Media } \\
\text { Massa }\end{array}$ & 4 & 13,4 & 7 & 23,34 & 1 & 3,34 & 12 & 40 \\
\hline 2 & Lingkungan & 1 & 3,34 & 2 & 6,7 & 6 & 20 & 9 & 30 \\
\hline 3 & $\begin{array}{l}\text { Petugas } \\
\text { kesehatan }\end{array}$ & 5 & 16,6 & 4 & 13,34 & - & - & 9 & 30 \\
\hline & Total & 10 & 33,34 & 12 & 43,38 & 7 & 23,34 & 30 & 100 \\
\hline
\end{tabular}

Berdasarkan tabel 4.1.5 diketahui dari 30 responden mayoritas mendapat sumber informasi dari Media Massa sebanyak 12 responden mayoritas berpengetahuan cukup sebanyak 7 responden $(23,34 \%)$, dari 9 responden yang mendapat informasi dari lingkungan mayoritas berpengetahuan cukup sebanyak 2 responden $(6,7 \%)$, dari 9 responden yang mendapat informasi dari petugas kesehatan mayoritas berpengetahuan cukup 4 responden $(13,34 \%)$.

\subsection{Pembahasan}

Dari penelitian yang berjudul "Gambaran Pengetahuan Ibu tentang Gangguan Pemusatan Perhatian Hiperaktif (GPPH)Di TK Bidayatul Hidayah Medan", maka diperoleh pembahasan sebagai berikut :

4.2.1. Pengetahuan Ibu Tentang Gangguan Pemusatan Perhatian Hiperaktif (GPPH) di TK Bidayatul Hidayah Medan

Berdasarkan tabel 4.1.1 diketahui bahwa dari 30 responden berpengetahuan cukup sebanyak $12(40 \%)$ responden, berpengetahuan kurang sebanyak 8 (26\%) responden. 
Hasil penelitian ini sesuai dengan pendapat Notoatmodjo (2007), yang menyatakan bahwa pengetahuan adalah hasil dari tahu, dan ini terjadi setelah orang melakukan penginderaan terhadap satu objek tertentu. Pengetahuan dicakup dalam domain kognitif yang mempunyai 6 tingkatan dan penelitian ini termasuk dalam tingkatan 2 yang menyatakan Comprehention (memahami) yang artinya suatu kemampuan untuk menjelaskan secara benar tentang objek yang diketahui dan dapat menginterprestasikan materi tersebut secara benar. Orang yang telah paham terhadap objek atau materi harus dapat menjelaskan dan menyebutkan.

Menurut asumsi penulis dari hasil penelitian ini menunjukan bahwa pengetahuan ibu tentang anak hiperaktif masih belum baik, di mana dari hasil penelitian lebih banyak ibu yang berpengetahuan cukup dan kurang dibanding berpengetahuan baik. Hal ini mungkin dikarenakan ibu-ibu yang masih belum memahami tentang anak hiperaktif saat ini. Maka dari itu peneliti melakukan penyuluhan tentang anak hiperaktif setelah pengumpulan kuesioner.

\subsubsection{Pengetahuan Ibu Berdasarkan Umur}

Berdasarkan tabel 4.1.2 diketahui dari 30 reponden mayoritas berusia 20 -35 tahun yaitu 20 responden dan mayoritas berpengetahuan cukup sebanyak 11 responden(33,33\%), dan dari responden yang berusia > 35 tahun mayoritas berpengetahuan cukup sebanyak 2 responden $(6,67 \%)$.

Hasil penelitian ini sesuai dengan pendapat Notoatmodjo (2007), yang menyatakan bahwa umur sangat erat hubungannya dengan tingkat pengetahuan seseorang karena semakin bertambahnya umur manusia semakin banyak pula pengalaman yang didapatnya.

Hasil ini juga sesuai dengan pendapat Hendra (2008) yang menyatakan bahwa bertambahnya umur seseorang dapat berpengaruh pada pertambahan pengetahuan yang diperolenhya, akan tetapi pada umurumur tertentu atau menjelang usia lanjut kemampuan penerimaan atau mengingat suatu pengetahuan akan berkurang.

Menurut asumsi penulis, faktor umur mempunyai pengaruh yang cukup besar terhadap baik, cukup dan kurangnya pengetahuan ibu. Dimana diketahui bahwa ibu yang berpengetahuan kurang disebabkan umur ibu yang masih muda sehingga ibu belum mempunyai banyak pengalaman dan sebaliknya ibu yang berpengetahuan baik dan cukup merupakan ibu yang berumur lebih dewasa, hal ini membuat ibu mempunyai lebih banyak pengalaman.

\subsubsection{Pengetahuan Ibu Berdasarkan Pendidikan}

Berdasarkan tabel 4.1.3 diketahui 30 responden, dapat dilihat dari 13 responden yang berpendidikan menengah mayoritas berpengetahuan cukup sebanyak 9 responden (30\%), dan dari 9 responden yang berpendidikan dasar mayoritas berpengetahuan cukup sebanyak 2 (6,7\%), dan dari 8 responden yang berpendidikan tinggi mayoritas berpengetahuan cukup sebanyak 2 responden $(6,7 \%)$.
Hasil penelitian ini sesuai dengan pendapat Notoatmodjo (2007) yang menyatakan bahwa, pendidikan memiliki peranan penting dalam menentukan kualitas manusia, dalam hal ini pendidikan juga berperan untuk membuat kehidupan yang lebih baik sebab makin tinggi pendidikan seseorang semakin banyak pengetahuannya dibanding seseorang yang tingkat pendidikannya rendah.

Hasil penelitian ini juga sesuai dengan pendapat Azwar (2005), yang menyatakan bahwa pendidikan mempunyai pengaruh penting dalam pembentukan pengetahuan, dikarenakan pendidikan meletakkan dasar pengertian dan konsep moral dalam individu. Dasar pengertian dan konsep moral akan sangat menetukan sistem kepercayaan sehingga konsep tersebut ikut berperan di dalam pembentukan pengetahuan tehadap suatu hal. Sekali kepercayaan terbentuk, maka ia akan menjadi dasar pengetahuan seseorang mengenai apa yang diharapkan dari objek itu

Ibu yang memiliki pendidikan lebih tinggi cenderung lebih banyak mendapat informasi tentang manfaat pelayanan kebidanan dibandingkan dengan ibu yang memiliki pendidikan lebih rendah.

Menurut asumsi penulis, faktor pendidikan mempunyai pengaruh yang cukup besar terhadap baik, cukup dan kurangnya pengetahuan ibu. Dimana diketahui bahwa ibu yang berpengetahuan kurang disebabkan pendidikan ibu yang rendah dan kurangnya memahami informasi dari luar dan sebaliknya ibu yang berpengetahuan baik dan cukup disebabkan ibu yang berpengetahuan tinggi, hal ini membuat ibu lebih mudah memahami informasi.

\subsubsection{Pengetahuan Ibu Berdasarkan Pekerjaan}

Berdasarkan tabel 4.1.4 diketahui dari 30 responden mayoritas bekerja yaitu 19 orang dan mayoritas berpengetahuan cukup sebanyak 7 responden $(23,3 \%)$ dari 11 responden tidak bekerja mayoritas berpengetahuan cukup sebanyak 5 responden $(16,6 \%)$

Hal penelitian ini sesuai dengan pendapat Notoatmodjo (2007), yang menyatakan bahwa pekerjaan sangat berpengaruh tehadap pengetahuan seseorang, dimana seseorang yang memiliki pekerjaan akan lebih cepat dan mudah untuk mendapat informasi. Hal ini karena lebih sering berinteraksi dengan orang lain yang menyebabkan memperoleh informasi dan pengetahuan.

Menurut asumsi penulis, faktor pekerjaan mempunyai pengaruh yang cukup besar terhadap baik, cukup dan kurangnya pengetahuan ibu. Dimana diketahui bahwa ibu yang berpengetahuan cukup disebabkan ibu yang tidak bekerja dan sebaliknya ibu yang berpengetahuan baik merupakan ibu yang bekerja.

\subsubsection{Pengetahuan Ibu Berdasarkan Sumber Informasi \\ Berdasarkan tabel 4.1.5 diketahui dari 30} responden mayoritas mendapat sumber informasi dari Media Massa sebanyak 12 responden mayoritas berpengetahuan cukup sebanyak 7 responden $(23,34 \%)$, dari 9 responden yang mendapat informasi dari lingkungan mayoritas berpengetahuan cukup sebanyak 2 responden 
$(6,7 \%)$, dari 9 responden yang mendapat informasi dari petugas kesehatan mayoritas berpengetahuan cukup 4 responden $(13,34 \%)$.

Hasil penelitian ini sesuai dengan pendapat Notoatmodjo (2007), yang menyatakan bahwa sumber informasi adalah segala sesuatu yang menjadi perantara dalam menyampaikan informasi, merangsang pikiran dan kemampuan seseorang.

Menurut asumsi penulis bahwa tingkat informasi ibu tentang anak hiperaktif yang sering dilihat dan didengar oleh ibu, itulah yang berpengaruh terhadap pengetahuan ibu. Hal ini dikarenakan banyaknya sumber informasi yang didapat oleh ibu dari petugas kesehatan tentang anak hiperaktif. Lokasi tempat tinggal dan TK juga dekat dengan sarana kesehatan, sehingga memudahkan para ibu untuk berkonsiltasi dengan petugas kesehatan. Sumber informasi merupakan faktor yang paling mempengaruhi pengetahuan para ibu, karena ibu mendapat penjelasan yang lebih mendetil dan spesifik tentang anak hiperaktif dari petugas keseh

\section{Simpulan}

Dari hasil penelitian tentang "Gambaran Pengetahuan Ibu Tentang Gangguan Pemusatan Perhatian Hiperaktif (GPPH) Di TK Bidayatul Hidayah Medan" dapat diambil kesimpulan sebagai berikut :

1. Pengetahuan ibu tentang anak hiperaktif berdasarkan kuesioner yang dibagikan sebanyak 20 pertanyaan yaitu mayoritas berpengetahuan baik.

2. Tingkat pengetahuan berdasarkan umur, ibu yang mayoritas berpengetahuan baik terdapat pada ibu yang berumur $>35$ tahun. Hal ini mungkin dikarenakan ibu-ibu tersebut memiliki pengalaman yang lebih banyak tentang anak hiperaktif.

3. Tingkat pengetahuan berdasarkan pendidikan, ibu yang mayoritas berpengetahuan cukup terdapat pada ibu yang berpendidikan tinggi. Hal ini mungkin dikarenakan ibu yang berpendidikan lebih tinggi lebih banyak mendapatkan pendidikan tentang anak hiperaktif dibandingkan dengan ibu yang berpendidikan menengah dan pendidikan dasar.
4. Tingkat pengetahuan berdasarkan pekerjaan, ibu yang mayoritas berpengetahuan baik terdapat pada ibu yang bekerja sebagai petugas kesehatan. Hal ini mungkin dikarenakan di tempat ibu bekerja ibu mendapatkan berbagai pengalaman tentang anak hiperaktif, sehingga ibu lebih mengerti tentang anak hiperaktif.

5. Tingkat pengetahuan berdasarkan paritas, ibu yang mayoritas berpengetahuan baik terdapat pada ibu primipara.

6. Tingkat pengetahuan berdasarkan sumber informasi, ibu yang mayoritas berpengetahuan baik terdapat pada ibu yang mendapatkan sumber informasi tentang anak hiperaktif dari petugas kesehatan. Hal ini mungkin dikarenakan petugas kesehatan mempunyai pengetahuan yang baik tentang anak hiperaktif dan lebih spesifik dalam memberikan informasi, sehingga para ibu menjadi lebih baik.

Berarti umur, pendidikan, pekerjaan, paritas dan sumber informasi merupakan faktor-faktor yang mempengaruhi pengetahuan.

\subsection{Saran}

1. Diharapkan kepada Kepala Sekolah dan para guru yang mengajar di TK Bidayatul Hidayah Medan untuk lebih sabar dan memberikan perhatian yang khusus serta memberikan arahan dan bimbingan semaksimal mungkin kepada anak-anak hiperaktif tersebut dan mengambilsebuah kebijakan.

2. Diharapkan kepada institusi pendidikan Bakti Inang Persada Medan untuk menjadikan materi Anak Hiperaktif sebagai salah satu bahan perkuliahan, sehingga para mahasisiwi akan lebih tahu dan terampil ketika menghadapi anak hiperaktif .

3. Diharapkan kepada Mahasiswi Akademi Kebidanan Bakti Inang Persada Medan agar melakukan penelitian lebih lanjut tentang "Anak hiperaktif” dengan variabel yang berbeda. 